\title{
Fluctuation of Fusarium distribution in soil and the role of the forecrop in the control of Fusarium wilt of flax
}

\section{H. ZARZYCKA *}

Institute of Native Natural Fibres in Poznań, Poland

(Received: 15 June, 1976)

\begin{abstract}
The influence of crop rotation and wheather conditions on the Fusarium population in soil and on Fusarium wilt of flax. was examined in the Institute of Native Natural Fibres in 1968-1975. The experiments were carried out in various regions of flax planting in Poland during 8 years. Crop rotation had a significant influence on the process of biological soil disinfestation. Fusarium population in soil increased after planting flax, wheat, barley and sugar-beet, and decreased or did not change after rape, hemp, potato and leguminous plants. The crop rotation significantly influenced the composition of the Fusarium population as far as species are concerned. The highest wilt infection of flax was found in plantings after flax, sugarbeet and wheat and the weakest in 'plantings after rape. A six-year crop rotation was sufficient to eliminate the wilt pathogen from infested soil. But on flax-sick soil the process of biological disinfestation proceeded more slowly and a seven-year interval between flax crops was too short.
\end{abstract}

\section{INTRODUCTION AND LITERATURE REVIEW}

Fusarium wilt is a serious threat to flax in Poland. The main source of infection is in the soil. Fusarium developing on flax may, after the vegetation season, continue to live in the soil in saprophytic state as mycelium and spores. Investigations on the surviving forms of these fungi in the soil were carried out by Buxton and $\mathrm{Kendrick}$ (1963) and $\mathrm{B}$ anih a s e mi and Deze e u (1973). The period of Fusarium survival in the soil was studied by Nash and A le xander (1965) and $\mathrm{K}$ o m m e nd a h 1 (1970).

A considerable accumulation of pathogens in the soil is one of the main causes of the phenomenon known as flax soil sickness (K r y n -

* Author's address: Dr. Hanna Zarzycka, Nubijska Str. 1/58, Warsaw, Poland. 
ski and $\mathrm{Zarzycka}$ 1972). This occurs more and more frequently in regions where flax cropping is intensive, particularly in the south of Poland, and it is probably a result of flax planters tendency to reduce the intervals between successive flax plantings.

The persistance of Fusarium in the soil depends on the fungistatic or mycolytic activity of antagonistic soil microorganisms. The most important organisms of this type are Actinomycetes (M essiaen et al. 1965; Van der Spek 1965; Wnękowski 1966), bacteria (Messiaen et al. 1965; Strzelczyk 1966; Lemaire 1968) and some fungi, especially Penicillium (Ka ufman and Williams 1965) and Trichoderma (B i s by et al. 1933; F ed orinčik 1968).

Investigations on the mechanisms of the antagonistic activity of these mikroorganisms towards various Fusarium species were performed by Meredith (1943), Messiaen et al. (1965), Strzelczyk (1966) and Lamaire (1968). The fluctuations of Fusarium distribution in the soil and composition of the antagonistic soil microflora are greatly affected by the plants cultivated in crop rotation, particularly those used as forecrop. Since besides the specialized $F$. oxysporum f. sp. lini there occur many other Fusarium species on flax such as $F$. avenaceum, $F$. culmorum, $F$. equiseti and $F$. scirpi $(\mathrm{Cz}$ y ż e w ska and $\mathrm{Zarzycka} 1968$ ), the crop rotation may have an important influence both on the development or the antagonistic microflora and on the accumulation in the soil of polyphagous Fusarium species which may infect flax. The latter species remain on infected residues of other crops; for instance after wheat the population of Fusarium culmorum in soil increased (G a r r t 1946 ; D o m sh et al. 1968), but the population of Fusarium oxysporum did not change ( $\mathrm{Z}$ i $1 \mathrm{ing} 1932$ ). On the other hand, leaving the land fallow has a favourable influence on the development of the antagonistic microflora (Krassilnikov 1946).

$\mathrm{Rataj}$ (1954) considers the clover with grasses as a favourable forecrop before flax, N e a f it a v a (1969) recommends clover, whereas Korneeva (1971) believes that clover increased the risk of flax infection with Fusarium wilt.

Investigations performed in Poland to date on the occurrence of flax soil-borne pathogens of the genus Fusarium ( $\mathrm{Za} \mathrm{rzycka} 1973$ ) revealed the causes of the quantitative and qualitative variations in composition of Fusarium during 2 years after flax cultivation.

In the present studies it was attempted to establish the period necessary for biological disinfestation of the soil after flax planting and the influence of the crop rotation on this process.

The results may serve as guiding lines for establish of an appropriate crop rotation which is one of the elements of complex control of $\mathrm{Fu}$ sarium wilt of flax. 
suo!ฺ

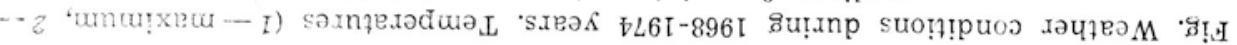

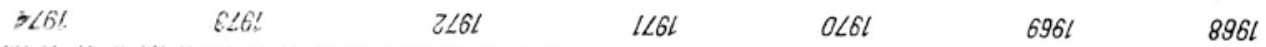

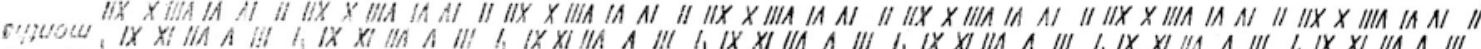

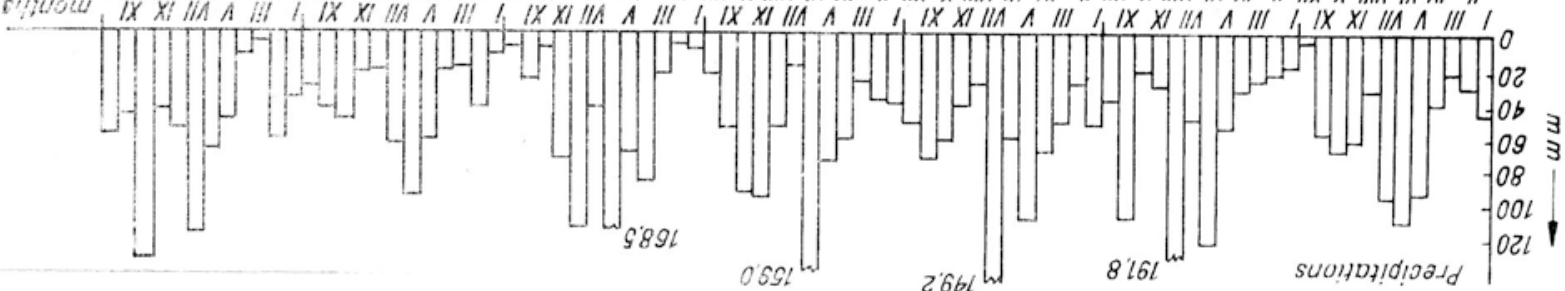

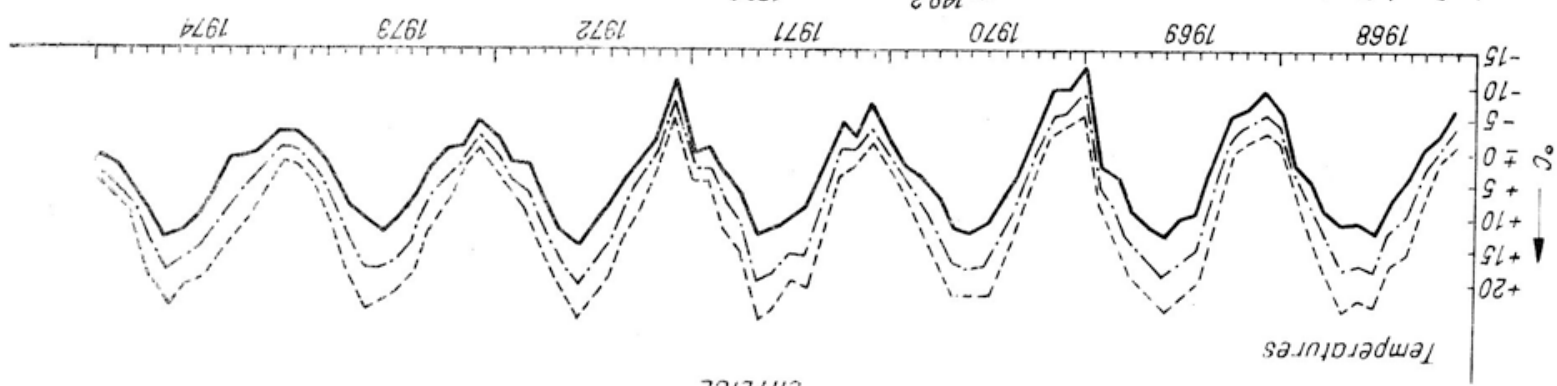

$33 / 7$ イHJ
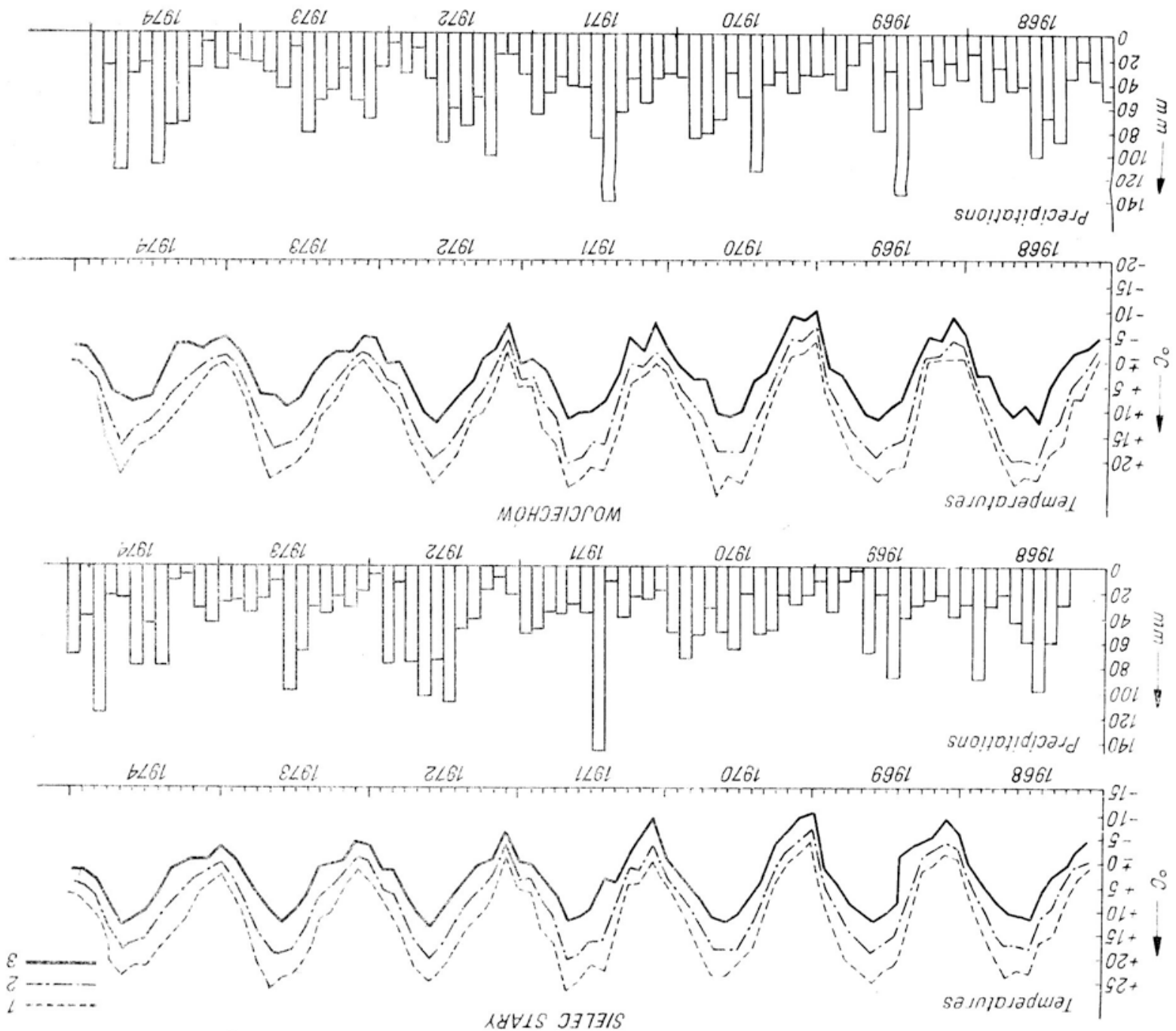

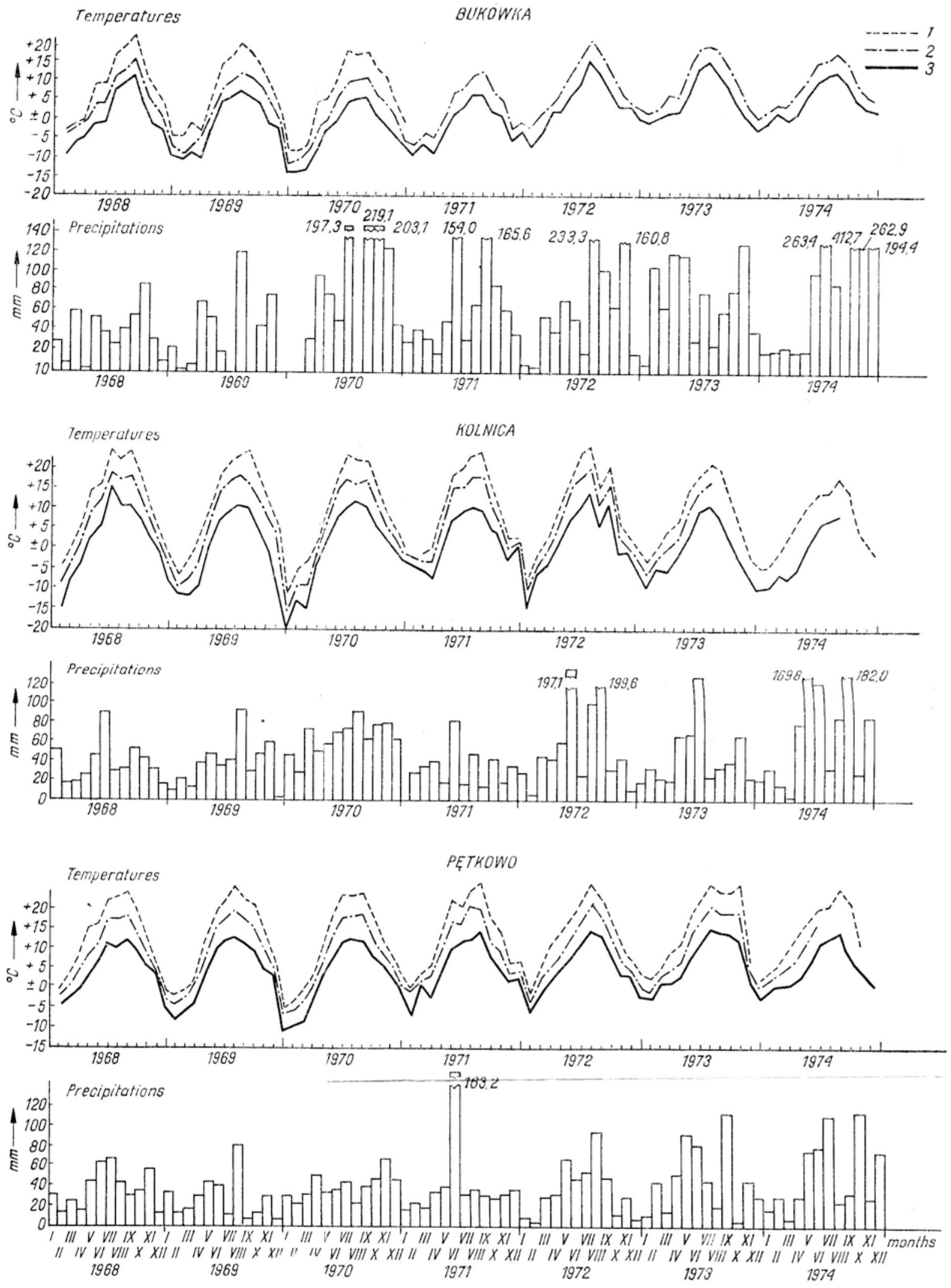

Fig. Weather conditions during 1968-1974 years. Temperatures ( 1 - maximum, 2 medium, 3 - minimum) and precipitations 


\section{MATERIAL AND METHODS}

Investigations were undertaken in the Institute of Native Natural Fibres in 1968-1975 on the quantitative occurrence and specific composition of Fusarium on 9 fields in various regions of flax cultivation during its planting and in the subsequent 7 vegetation seasons at the following Experimental Stations:

1. Bukówka, Słupsk district, soil type: sandy-loamy podsol on heavy clay;

2. Kolnica, Suwalki district, soil type: podsol on boulder clay;

3. Pętkowo, Poznan district, soil type: black earth on sandy loam;

4. Sielec Stary, Leszno district, soil type: brown earth, loamy sand on clay;

5. Wojciechów, Częstochowa district, soil type: loamy-sandy podsolic soil on sand-gravel ( 3 fields were chosen here II, IV and Walce II).

6. Chylice, Warsaw district, soil type: podsol on clay loam (2 fields chosen: A and B). On field A flax was grown from 1961 to 1965 , then oats, potatoes and again flax in 1968. The plantation was then infested with Fusarium wilt in 100 per cent. On field B, beginning with 1961 flax was cultivated for 2 years, then oats, potatoes, flax, oats, potatoes and flax in 1968, infestation in that year did not exceed 60 per cent.

The crop rotation on the chosen experimental fields during the period of experiments is given in Table 1.

In the year when flax was grown soil samples were taken from the rhizosphere for examination: in spring at the stage of flax seedlings and before shooting, and in summer in the period of blooming, a third sample was collected in autumn after the harvest from randomly chosen places on the field. In the following years soil samples were taken twice: in spring and in autumn from randomly chosen places on the field.

The quantitative occurrence and qualitative composition of Fusarium species in the soil samples was established by the modified method of successive dilutions described by Maciejow ska (1967). The air-dry soil sample was mixed with potate dextrose agar with addition of $1 \mathrm{ppm}$ Bengal rose and $1 \mathrm{ppm}$ streptomycin sulphate. Dilutions of the order $10^{-4}, 10^{-6}$, and $10^{-8}$ were poured into Petri dishes. The number of $\mathrm{Fu}$ rium colonies was counted after 7 days of incubation at $20-22^{\circ} \mathrm{C}$.

The results were converted to $1 \mathrm{~g}$ of soil. On the basis of up-to-date observations less than 1000 fungus propagules in $1 \mathrm{~g}$ of soil was considered as a level not hazardous to flax plantations. Fusarium species were identified according to B o o th's key (1971).

The pathogenicity of $F$. oxysporum f. sp. lini and other Fusarium species was tested in laboratory conditions by inoculating with spore 
suspension 100 flax seedlings on filter paper cylinders in test tubes of $28 \times 200 \mathrm{~mm}$ dimensions.

From the same soil samples fungi antagonistic to Fusarium spp. were also isolated. The antagonism of these organisms towards various species of the genus Fusarium was tested on Petri dishes on potato dextrose agar by measuring the growth inhibition zone.

\section{Observations on the influence of the forecrop on flax infection} with Fusarium wilt

The experiments were carried out in Wojciechów in 1970-1974 on podsolized sandy loam soil on a sand-gravel subsoil. The forecrops in 3 years preceding the experiments are shown in Table 3. In 1970-1972 the flax cultivar Milenium and in 1973-1974 the cultivar Fortuna were sown in the amount of $140 \mathrm{~kg} / \mathrm{h}$. The experiments were conducted in 4 replications, the plot size were in 1970-1971 - $6 \mathrm{~m}^{2}$ and in 1972-1974 $-10 \mathrm{~m}^{2}$.

Observations on infection of the plants were made towards the end of the vegetation period in the stage of seed maturity, by counting the diseased and healthy plants in the middle rows of each plot.

\section{RESULTS}

Fusarium populations in the soil

In the soil samples taken from the rhizosphere of plants infected with Fusarium wilt the frequency of Fusarium spp. was very high, reaching 81000 fungus propagules in $1 \mathrm{~g}$ of soil, whereas in samples of soil collected after the flax harvest it was much lower (Table 1).

In the subsequent years after flax planting the Fusarium population in the soil markedly decreased showing sometimes seasonal fluctiations: a decrease in spring and increase in autumn. The decrease in the frequency of Fusarium in the soil was noted on many fields after the winter periods 1968-1969 and 1969-1970 and in Pętkowo and Bukówka in 1971-1972. This was elearly associated with weather conditions: severe frost with relatively low precipitation. An increase in the-frequency of Fusarium spp. was noted in the vegetative season in the years 1969, 1970 and in some cases in 1971 (Bukówka and Pętkowo) and in 1972 (Wojciechów and Kolnica). It was usually connected with high precipitation and moderate air temperature about $20^{\circ} \mathrm{C}$.

In general the frequency of Fusarium in the soil decreased to a level which would not threaten flax crop in course of 5-year period after flax cultivation in Pętkowo, Bukówka, Kolnica and on fields II and IV in Wojciechów. On the other hand in the soil of Chylice and 
Sielec Stary the Fusarium population in the soil was still very high in 5-6 years after the flax culture was ceased.

The plants grown in the crop rotation were greatly influencing the state of soil infestation with Fusarium. A distinct increase of its occurence in the soil was noted after flax and sugar-beet plantings and after some cereals such as wheat and barley.

After cultivation of leguminous crops, mixture of cereal and leguminous crops, potatoes and hemp the frequency of Fusarium occurrence in the soil varied only slightly, while after rape and cereals like rye, oats and maize it showed a marked decreasing tendency (Table 1).

The spectrum of Fusarium species isolated from the soil was rather varied (Table 2). F. oxysporum Schl. and F. o. f. sp. lini (Bolley) Snyd. et Hans. was most numerously represented. The freauency of the letter species decreased gradually during the 8 years of study. In last years of experiment it was being found in soil samples only sporadically. The frequency of $F$. o. f. sp. lini also decreased and in the last samples collected in Kolnica, Pętkowo and Sielec Stary this form was not detected at all. On the other hand, in the latest samples from flax-sick soils in Chylice and Wojciechów a high soil infestation with this species was noted.

$F$. equiseti (Corda) Sacc. was very common. Its frequency diminished brit not regularity could be found in these fluctuations. F. solani (Mart.) Sacc. was more frequently detected after cereals, potatoes, beets and leguminous crops. F. culmorum (W. G. Smith) Sacc. was rather rare and found mostly on fields where cereals had been grown. The sporadic occurrence of $F$. avenaceum (Corda ex Fr.) Sacc. was connected with maize and cereals plantations. $F$. sambucinum Fuckel also occurred sporadically.

Species of the genus Penicillium and Trichoderma were isolated as representatives of the atagonistic fungi. In soil samples collected in the first years of investigation various species of Penicillium prevailed. The level of their occurrence varied within the range of 5 do 40 thousands of fungi propagules in $1 \mathrm{~g}$ of soil. Trichoderma provailed in the soil samples of the 5th and 6th year following flax plantings. Their occurrence varied within the limits of 1 to 25 thousands of fungi propagules in $1 \mathrm{~g}$ of soil. The number of antagonistic fungi increased after leguminous crops.

\section{Influence of forecrop on infestation of flax with Fusarium wilt}

Of all the forecrop sequences applied most favourable seems to be the 3 years' set: peas in first year, then green fodder clover and winter rape directly before flax as was shown in 1973 in experiment I 


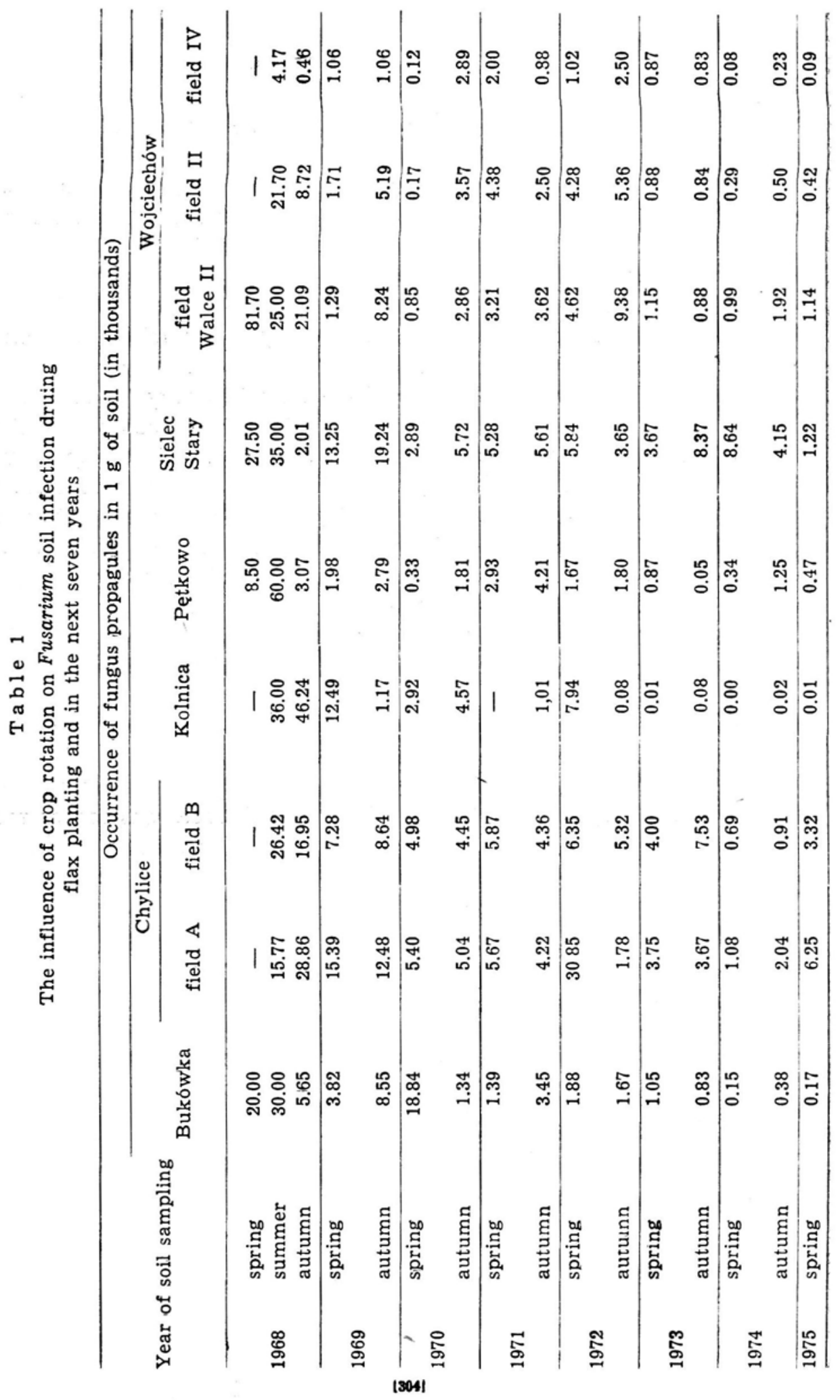




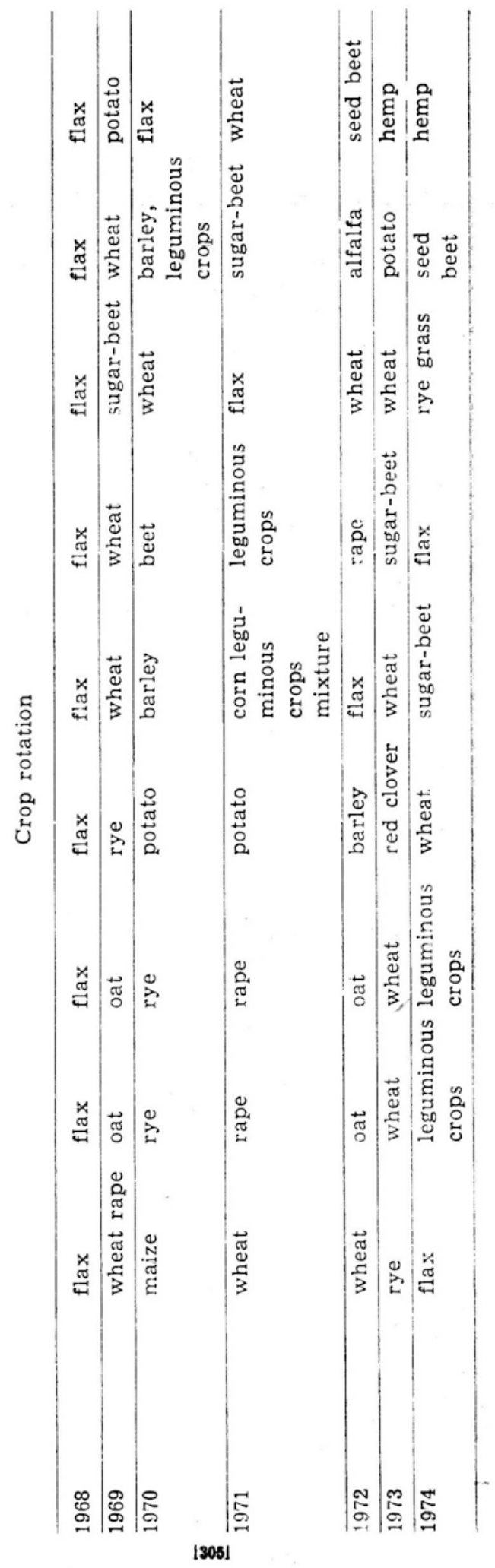


T a ble 2

The species of Fusarium in soil from/different tested fields

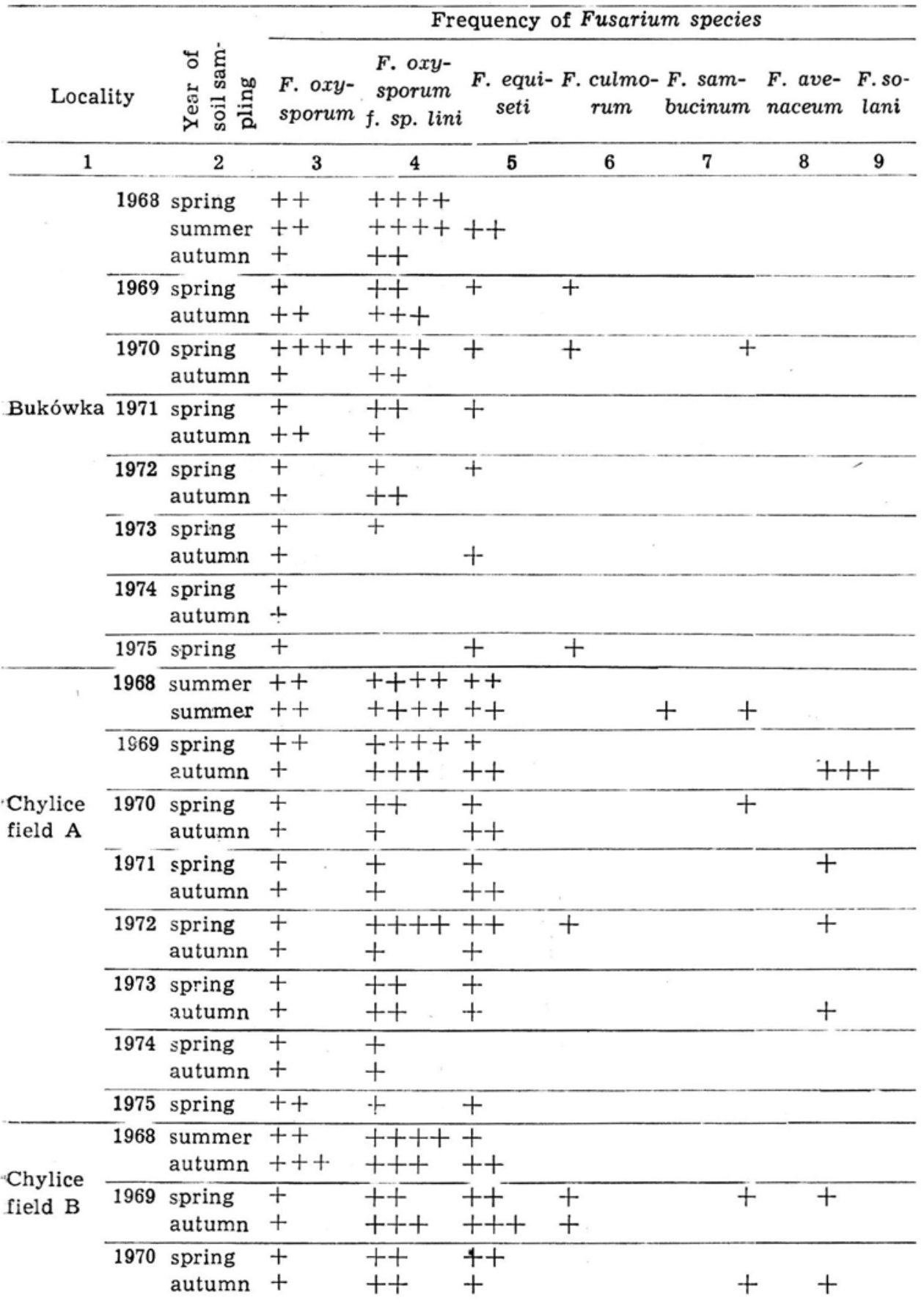




\begin{tabular}{|c|c|c|c|c|c|c|c|}
\hline 1 & & 2 & 3 & 4 & 6 & 7 & 8 \\
\hline & 1971 & $\begin{array}{l}\text { spring } \\
\text { autumn }\end{array}$ & $\begin{array}{l}+ \\
+ \\
\end{array}$ & $\begin{array}{l}++ \\
++\end{array}$ & $\begin{array}{l}+ \\
++\end{array}$ & & \\
\hline \multirow[t]{7}{*}{$\begin{array}{l}\text { Chylice } \\
\text { field B }\end{array}$} & 1972 & $\begin{array}{l}\text { spring } \\
\text { autumn }\end{array}$ & $\begin{array}{l}++ \\
+\end{array}$ & $\begin{array}{l}++ \\
++\end{array}$ & + & & \\
\hline & 1973 & $\begin{array}{l}\text { spring } \\
\text { autumn }\end{array}$ & $\begin{array}{l}+ \\
++\end{array}$ & $\begin{array}{l}++ \\
++\end{array}$ & + & & + \\
\hline & 1974 & $\begin{array}{l}\text { spring } \\
\text { autumn }\end{array}$ & $\begin{array}{l}+ \\
+\end{array}$ & $\begin{array}{l}+ \\
+\end{array}$ & + & & \\
\hline & 1975 & spring & ++ & + & + & & \\
\hline & 1968 & $\begin{array}{l}\text { summer } \\
\text { autumn }\end{array}$ & $\begin{array}{l}+++ \\
+++ \\
\end{array}$ & $\begin{array}{l}+++ \\
++++\end{array}$ & $\begin{array}{l}+++++ \\
+++\end{array}$ & ++ & \\
\hline & 1969 & $\begin{array}{l}\text { spring } \\
\text { autumn }\end{array}$ & $\begin{array}{l}++ \\
+\end{array}$ & $\begin{array}{l}++ \\
+\end{array}$ & $\begin{array}{l}+++ \\
+\end{array}$ & + & + \\
\hline & 1970 & $\begin{array}{l}\text { spring } \\
\text { autumn }\end{array}$ & $\begin{array}{l}+ \\
+ \\
\end{array}$ & + & $\begin{array}{ll}+ & ++ \\
++ & +\end{array}$ & & + \\
\hline \multirow[t]{8}{*}{ Kolnica } & 1971 & $\begin{array}{l}\text { spring } \\
\text { autumn }\end{array}$ & + & & + & & \\
\hline & 1972 & $\begin{array}{l}\text { summer } \\
\text { autumn }\end{array}$ & $\begin{array}{l}++ \\
+ \\
\end{array}$ & + & ++ & & + \\
\hline & 1973 & $\begin{array}{l}\text { spring } \\
\text { autumn }\end{array}$ & $\begin{array}{l}+ \\
+ \\
\end{array}$ & & $\begin{array}{l}+ \\
+ \\
\end{array}$ & & \\
\hline & 1974 & $\begin{array}{l}\text { spring } \\
\text { autunm }\end{array}$ & + & & + & & \\
\hline & 1975 & spring & & & + & & \\
\hline & 1968 & $\begin{array}{l}\text { spring } \\
\text { summer } \\
\text { autumn }\end{array}$ & $\begin{array}{l}++ \\
+ \\
\end{array}$ & $\begin{array}{l}++++ \\
+\end{array}$ & $\begin{array}{ll}++ & ++ \\
++++ & ++ \\
++ & +\end{array}$ & $\begin{array}{l}++ \\
+ \\
\end{array}$ & $\begin{array}{l}++ \\
+++\end{array}$ \\
\hline & 1969 & $\begin{array}{l}\text { autumn } \\
\text { spring }\end{array}$ & $\begin{array}{l}+ \\
+ \\
\end{array}$ & $\begin{array}{l}+ \\
+\end{array}$ & $\begin{array}{ll}+ & + \\
++ & +\end{array}$ & & + \\
\hline & 1970 & $\begin{array}{l}\text { autumn } \\
\text { spring }\end{array}$ & $\begin{array}{l}+ \\
+ \\
\end{array}$ & $\begin{array}{l}+ \\
+\end{array}$ & $\begin{array}{l}+ \\
+\end{array}$ & & \\
\hline \multirow[t]{4}{*}{ Pęt'kowo } & 1971 & $\begin{array}{l}\text { spring } \\
\text { autumn }\end{array}$ & $\begin{array}{l}+ \\
++\end{array}$ & $\begin{array}{l}+ \\
+\end{array}$ & $\begin{array}{l}+ \\
++\end{array}$ & . & + \\
\hline & 1972 & $\begin{array}{l}\text { spring } \\
\text { autumn }\end{array}$ & $\begin{array}{l}+ \\
+ \\
\end{array}$ & $\begin{array}{l}+ \\
++\end{array}$ & + & & + \\
\hline & 1973 & $\begin{array}{l}\text { spring } \\
\text { autumn }\end{array}$ & + & $\begin{array}{l}+ \\
+\end{array}$ & + & + & \\
\hline & 1974 & $\begin{array}{l}\text { spring } \\
\text { autumn }\end{array}$ & $\begin{array}{l}+ \\
+ \\
\end{array}$ & $\begin{array}{l}+ \\
+ \\
\end{array}$ & + & & \\
\hline . & 1975 & spring & + & + & + & & \\
\hline \multirow[t]{2}{*}{$\begin{array}{l}\text { Sielec } \\
\text { Stary }\end{array}$} & 1968 & $\begin{array}{l}\text { spring } \\
\text { summer } \\
\text { autumn }\end{array}$ & $\begin{array}{l}++ \\
++ \\
+ \\
\end{array}$ & $\begin{array}{l}++++ \\
+++ \\
+\end{array}$ & $\begin{array}{l}+++++++ \\
++++ \\
++\end{array}$ & + & \\
\hline & 1969 & $\begin{array}{l}\text { spring } \\
\text { autumn }\end{array}$ & + & $\begin{array}{l}++ \\
+++\end{array}$ & $\begin{array}{l}++++ \\
+++\end{array}$ & & + \\
\hline
\end{tabular}




\begin{tabular}{|c|c|c|c|c|c|c|c|c|c|}
\hline 1 & & 2 & 3 & 4 & 5 & 6 & 7 & & 8 \\
\hline & 1970 & $\begin{array}{l}\text { spring } \\
\text { autumn }\end{array}$ & + & $\begin{array}{l}+ \\
+\end{array}$ & $\begin{array}{l}+ \\
++\end{array}$ & & & & $\begin{array}{l}+ \\
+\end{array}$ \\
\hline Sielec & 1971 & $\begin{array}{l}\text { spring } \\
\text { autumn }\end{array}$ & $\begin{array}{l}++ \\
++\end{array}$ & $\begin{array}{l}+ \\
+\end{array}$ & $\begin{array}{l}++ \\
++\end{array}$ & & + & & \\
\hline \multirow[t]{6}{*}{ Stary } & 1972 & $\begin{array}{l}\text { spring } \\
\text { autumn }\end{array}$ & $\begin{array}{l}++ \\
++\end{array}$ & $\begin{array}{l}+ \\
+\end{array}$ & $\begin{array}{l}+ \\
+\end{array}$ & & & & ++ \\
\hline & 1973 & $\begin{array}{l}\text { spring } \\
\text { autumn }\end{array}$ & $\begin{array}{l}++ \\
++\end{array}$ & $\begin{array}{l}+ \\
+ \\
\end{array}$ & $\begin{array}{l}+ \\
++\end{array}$ & + & & & \\
\hline & 1974 & $\begin{array}{l}\text { autumn } \\
\text { spring }\end{array}$ & $\begin{array}{l}++ \\
+ \\
\end{array}$ & $\begin{array}{l}+ \\
++\end{array}$ & $\begin{array}{l}++ \\
+\end{array}$ & & & & \\
\hline & 1975 & spring & + & + & & & & & \\
\hline & 1968 & $\begin{array}{l}\text { summer } \\
\text { autumn }\end{array}$ & $\begin{array}{l}+ \\
+ \\
\end{array}$ & $\begin{array}{l}+++ \\
++\end{array}$ & $\begin{array}{l}+++ \\
++\end{array}$ & & + & & \\
\hline & 1969 & $\begin{array}{l}\text { spring } \\
\text { autumn }\end{array}$ & $\begin{array}{l}+ \\
++\end{array}$ & $\begin{array}{l}+ \\
+ \\
\end{array}$ & $\begin{array}{l}+ \\
++\end{array}$ & + & & & ++ \\
\hline Woj- & 1970 & $\begin{array}{l}\text { spring } \\
\text { autumn } \\
\end{array}$ & $\begin{array}{l}+ \\
+\end{array}$ & $\begin{array}{l}+ \\
+\end{array}$ & $\begin{array}{l}+ \\
++\end{array}$ & & & & \\
\hline ciechów & 1971 & $\begin{array}{l}\text { spring } \\
\text { autumn }\end{array}$ & $\begin{array}{l}+ \\
+ \\
\end{array}$ & $\begin{array}{l}++ \\
+\end{array}$ & $\begin{array}{l}+ \\
+ \\
\end{array}$ & & & & ++ \\
\hline \multirow[t]{6}{*}{ field II } & 1972 & $\begin{array}{l}\text { spring } \\
\text { autumn }\end{array}$ & $\begin{array}{l}++ \\
++\end{array}$ & $\begin{array}{l}+ \\
+ \\
\end{array}$ & $\begin{array}{l}+ \\
+ \\
\end{array}$ & & & & + \\
\hline & 1973 & $\begin{array}{l}\text { spring } \\
\text { autumn }\end{array}$ & $\begin{array}{l}+ \\
+\end{array}$ & $\begin{array}{l}+ \\
+\end{array}$ & + & & & & + \\
\hline & 1974 & $\begin{array}{l}\text { spring } \\
\text { autumn }\end{array}$ & $\begin{array}{l}+ \\
+\end{array}$ & + & + & & & & + \\
\hline & 1975 & spring & + & & + & & & & \\
\hline & 1968 & $\begin{array}{l}\text { spring } \\
\text { summer } \\
\text { autumn }\end{array}$ & $\begin{array}{l}++++ \\
+++ \\
++\end{array}$ & $\begin{array}{l}++++ \\
++++ \\
++++\end{array}$ & $\begin{array}{l}++++ \\
+ \\
++\end{array}$ & & $\begin{array}{l}++ \\
++\end{array}$ & + & + \\
\hline & 1969 & $\begin{array}{l}\text { spring } \\
\text { autumn }\end{array}$ & $\begin{array}{l}+ \\
++\end{array}$ & $\begin{array}{l}++ \\
++\end{array}$ & $\begin{array}{l}+ \\
+ \\
\end{array}$ & & & & + \\
\hline Woj- & 1970 & $\begin{array}{l}\text { spring } \\
\text { autumn }\end{array}$ & $\begin{array}{l}+ \\
++\end{array}$ & $\begin{array}{l}+ \\
+ \\
\end{array}$ & $\begin{array}{l}+ \\
+\end{array}$ & + & & & \\
\hline ciechów & 1971 & $\begin{array}{l}\text { spring } \\
\text { autumn }\end{array}$ & + & $\begin{array}{l}++ \\
++\end{array}$ & $\begin{array}{l}+ \\
++\end{array}$ & + & & & \\
\hline field & 1972 & $\begin{array}{l}\text { spring } \\
\text { autumn }\end{array}$ & $\begin{array}{l}+ \\
++\end{array}$ & $\begin{array}{l}++ \\
++ \\
\end{array}$ & $\begin{array}{l}+ \\
++\end{array}$ & + & & + & \\
\hline \multirow[t]{3}{*}{ Walce II } & 1973 & $\begin{array}{l}\text { spring } \\
\text { autumn }\end{array}$ & $\begin{array}{l}+ \\
+\end{array}$ & $\begin{array}{l}+ \\
+\end{array}$ & + & + & & + & \\
\hline & 1974 & $\begin{array}{l}\text { spring } \\
\text { autumn }\end{array}$ & $\begin{array}{l}+ \\
+ \\
\end{array}$ & $\begin{array}{l}+ \\
+ \\
\end{array}$ & + & & . & & \\
\hline & 1975 & spring & + & + & + & & & & \\
\hline
\end{tabular}




\begin{tabular}{|c|c|c|c|c|c|c|c|c|c|}
\hline 1 & & 2 & 3 & 4 & 5 & 6 & 7 & 8 & 9 \\
\hline & $\begin{array}{l}1968 \\
1969\end{array}$ & $\begin{array}{l}\text { summer } \\
\text { autumn } \\
\text { spring } \\
\text { autumn }\end{array}$ & $\begin{array}{l}++ \\
+ \\
+ \\
+\end{array}$ & $\begin{array}{l}++ \\
+ \\
+ \\
+\end{array}$ & $\begin{array}{l}+ \\
+ \\
+ \\
+\end{array}$ & + & + & & \\
\hline Woj- & 1970 & $\begin{array}{l}\text { spring } \\
\text { autumn }\end{array}$ & $\begin{array}{l}+ \\
+\end{array}$ & $\begin{array}{l}+ \\
++\end{array}$ & $\begin{array}{l}+ \\
+ \\
\end{array}$ & & & & \\
\hline ciechów & 1971 & $\begin{array}{l}\text { spring } \\
\text { autumn }\end{array}$ & $\begin{array}{l}+ \\
+\end{array}$ & $\begin{array}{l}++ \\
+ \\
\end{array}$ & + & & & & \\
\hline \multirow[t]{4}{*}{ field IV } & 1972 & $\begin{array}{l}\text { spring } \\
\text { autumn }\end{array}$ & $\begin{array}{l}+ \\
+ \\
\end{array}$ & $\begin{array}{l}+ \\
+ \\
\end{array}$ & $\begin{array}{l}+ \\
+ \\
\end{array}$ & & & & \\
\hline & 1973 & $\begin{array}{l}\text { spring } \\
\text { autumn }\end{array}$ & $\begin{array}{l}+ \\
+\end{array}$ & & $\begin{array}{l}+ \\
+ \\
\end{array}$ & & & & \\
\hline & 1974 & $\begin{array}{l}\text { spring } \\
\text { autumn }\end{array}$ & + & & $\begin{array}{l}+ \\
+ \\
\end{array}$ & & & & \\
\hline & 1975 & spring & & & + & & & & \\
\hline
\end{tabular}

Note: **** very high occurrence of Fusarium species: more than 10000 fungus propagules in $1 \mathrm{~g}$ of soil,

*** high occurrence of Fusarium species: 5000-10 000 fungus propagules in $1 \mathrm{~g}$ of soil,

** medium occurrence of Fusarium species: $1000-5000$ fungus propagules in $1 \mathrm{~g}$ of soil,

* low occurrence of Fusarium species: less than 1000 fungus propagules in $1 \mathrm{~g}$ of soil.

Table 3

The influence of three - years forecrops on Fusarium wilt of flax in Wojciechów $(1970-1974)$

\section{Forecrops previous to flax}

Percentage of infected plants in

Years

3rd year ahead 2nd year ahead 1 year ahead seed maturity stage

$\begin{array}{llllr}1970 & \text { flax } & \text { winter wheat } & \text { sugar-beet } & 48.8 \\ 1971 & \begin{array}{l}\text { green fodder } \\ \text { alfalfa }\end{array} & \text { rape } & \text { sugar-beet } & 36.0 \\ 1972 & \text { rape } & \text { sugar beet } & \text { flax } & 73.2 \\ 1973 \text { I } & \text { pea } & \begin{array}{l}\text { green fodder } \\ \text { clover }\end{array} & \text { winter rape } & 12.0 \\ 1973 \text { II } & \begin{array}{l}\text { spring barley } \\ \text { with alfalfa }\end{array} & \text { alfalfa } & \text { flax } & 59.1 \\ 1974 & \text { hemp } & \text { winter wheat } & \text { sugar-beet } & 27.5\end{array}$


(Table 3). In this experiment flax infection with Fusarium wilt was low, not exceeding 12 per cent, although the weather conditions favoured infection (dry weather between June and July and teperature exceeding $25^{\circ} \mathrm{C}$ ). In experiment II in the same year where the immediate forecrop was flax, infection of the plants reached almost 60 per cent. The least favourable seems to be crop rotation used in 1972: rape, sugar-beet and flax. Infection of the plants exceeded 73 per cent. The weather conditions in that year favoured infection (dry weather in the beginning of June and of July and rather high temperatures). When sugar-beet was the immediate forecrop as in 1970, 1971 and 1974 the per cent of plants infected with Fusarium wilt depended on the weather conditions and varied from 27,5 per cent in 1974 when these conditions were unfavourable to disease development (high humidity and relatively low temperature) to 48,8 per cen in 1970 when the weather favoured spread of Fusarium wilt.

\section{DISCUSSION}

The frequency of Fusarium in the soil is the result of two processes: multiplication and spread of the fungus which can live in saprophytic form on residues of organic matter in the soil on the one hand and of the mycolytic and fungistatic activity of antagonistic soil microorganisms on the other hand. Hence even a high level of Fusarium spp. in the soil in the period of flax cultivation does not mean this soil is strongly and above all durably infested. Thus, in spite of high soil contamination during flax cultivation in Kolnica, 4 years later the frequency of Fusarium spp. decreased considerably, and the level of $F$. oxysporum f. sp. lini fell to zero. This indicates a weak spreading ability of Fusarium spp. in the soil and good conditions for the development of antagonistic microorganisms. Moreover, the weather conditions in this region do not favour the development of Fusarium wilt. This is in agreement with the local observations on this disease. Fusarium wilt of flax is no problem in Kolnica.

On the other hand, on the flax-sick fields in Chylice strongly infested with Fusarium, the process of biological disinfestation proceeded very slowly. This is connected both with the high accumulation of the pathogens in the soil and with the poor development of the antagonistic microflora.

The process of biological soil disinfestation is influenced by many factors such as type of soil, kind and doses of fertilizers applied, plants grown as forecrop and weather conditions. All these factors affect both the fungi ability to spread in the soil and to survive and the development of antagonistic soil microflora. The experiments on soil infestation 
with Fusarium have shown that the factor decisive for the frequency of Fusarium occurence in the soil and the change of Fusarium wilt of flax was the crop rotation and particularly the forecrop. Too frequent planting of flax on the same field, as was the case in Chylice and Wojciechów, led to a high accumulation of the pathogen in the soil and caused weaker ability of biological soil disinfestation. According to the data of the Progress Report (1950) a 5-year interval in flax cultivation with the application of suitable crop rotation was sufficient to eliminate the risk of Fusarium wilt infection, and after a 7-year interval the high yield of flax fibre was obtained.

In the present investigations a 5-year interval between flax crop ensured soil disinfestation only in the case of "healthy" soil with a high population of microorganisms antagonistic to Fusarium. In flax-sick soil in which large quantities of the wilt pathogen were accumulated, the process of biological disinfestation was much slower, probably owing to the weaker development of the antagonistic organisms, and then even a 7-year crop rotation proved too short.

The plants grown in crop rotation, particularly as forecrop considerably influence the level of Fusarium in the soil and the risk of flax infection with wilt. It should be stressed here that no data for the Polish conditions were available, and the literature data are scarce and frequently controversial. Therefore the present experiments were treated as preliminary. In view of this, soil was examined from fields with a crop rotation normally applied in the given farm. In further investigations in progress in the Institute of Native Natural Fibres the crop sequence is established according to a plan based on the results of up-to-date studies.

Flax is the most unfavourable forecrop of all examined crops, as was shown in investigation on the level of Fusarium in the soil and observations on plant infection. The unfavourable forecrops for flax from the phytopathological point of view are some cereals such as wheat and barley, after cultivation of which the level of Fusarium in the soil rises as a rule. A high infection of flax grown after wheat was also observed. When oats and rye were sown as a forecrop the amount of Fusarium in the soil decreased. The literature data do not completely agree with the results presently obtained. Marchionat to (1954) considers that wheat and maize hand a favourable influence, reducing the risk of Fusarium wilt of flax, and $\mathrm{Rataj}$ (1954) and Nea f i t a v a (1969) observed a higher infaction on flax planted after rye.

Sugar-beet should be classed as a next unfavourable forecrop, which arised as a result of experiments on soil infestation and plant infection.

Leguminous crops particularly clover may be considered as a good 
forecrop, since after their cultivation Fusarium infestation did not increase and frequently even decreased. The use of clover as forecrop is controversial: Neafitava (1969) observed a lower infection of flax planted after clover, whereas Korneeva (1971) believes that clover cultivation enhances the chance of flax infection with Fusarium wilt. According to the data of the Progress Report (1950), clover and grasses had a favourable effect on the process of biological disinfestation and reduced the risk of flax infection with $F$. oxysporum $\mathrm{f}$. sp. lini.

In the present experiments cultivation of a mixture of leguminous and cereal plants increased the Fusarium level in the soil, but flax planted after them was relatively little infected. On the other hand, $R$ a t a j (1954) considers such mixtures as favourable to biological soil disinfestation.

Rape and potatoes belong to plants which as forecrop lowered the frequency of Fusarium occurence in the soil. Flax planted directly after these plants was little infected with wilt. No information is found in the available literature about rape as a forecrop, whereas after potatoes $\mathrm{Ne}$ afitava (1969) observed a relatively high infection of flax with Fusarium.

Fertilization influences the process of biological soil disinfestation however, since the chois of fertilizers and their doses were strictly bound with the kind of crop planted, it is difficult to separate these problems. Since Timonin (1940) affirms that the level of $F$. oxysporum f. sp. lini is influenced more by the crop planted than by the intensity of fertilization, attention was mainly devoted, when considering these problems, to the plants included in crop rotation.

Weather conditions play an important role in the occurrence of $\mathrm{Fu}$ sarium in the soil and the chance of flax infection with Fusarium wilt. Fungi of the genus Fusarium, particularly $F$. oxysporum have relatively high temperature requirements. As observed in the experiments, the fungi developed in the soil best about $20^{\circ} \mathrm{C}$ with relatively high rainfall. On the other hand, low temperature, frost and dry weather had an unfavourable influence on Fusarium occurence in the soil. This may probably explain the phenomenon that on fields in the northern regions of the country the process of biological disinfestation was much quicker than in central or southern Poland.

It should be mentioned, however, that the risk of flax infection with Fusarium wilt does not solely depend on the degree of accumulation of the pathogen in the soil, but also on conditions favouring infection. Fusarium wilt infects flax most intensively usually after a period of dry weather and high air temperature, which lower the resistance of plants and favour the wilt infection. Since such conditions 
prevail more frequently in the southern regions of flax plantation than in the northern ones, therefore in Sielec Stary or Wojciechów the risk of flax infection is much higher than in Bukówka or Kolnica, even if the level of pathogen population in the soil is the same.

With progressing concentration and intensification of flax production exceptionally favourable conditions arise for more and more frequent flax-sickness of the soil, particularly in the southern regions. Therefore attention should be payed to the necessity of a long interval between flax plantings and the cultivation of appropriate forecrops.

\section{CONCLUSIONS}

1. The degree of soil infestation with Fusarium, high during flax cultivation decreased gradually over the 7 years of observation.

2 . The process of biological soil disinfestation was faster on "healthy" than on flax-sick soils. On the former a 5-year interval in flax cultivation was sufficient.

3. For soil brought by too frequent flax cultivation to a state of flax-sickness a 7-year interval between the flax plantings was too short.

4. The forecrop for flax influenced the fluctuation of Fusarium distribution in the soil:

a. the frequency of Fusarium population in soil and infection of flax with Fusarium wilt increased after flax, wheat, barley and sugarbeet,

b. the frequency of Fusarium population in soil decreased or did not change and the flax was rarely infected with Fusarium wilt after leguminous crops, rape, hemp, potatoes, rye oats and maize.

5. The level of Fusarium population in the soil was affected by weather conditions. The pathogen developed best at an air temperature of about $20^{\circ} \mathrm{C}$ with high air humidity, whereas frost and dry weather limited the development of Fusarium.

\section{REFERENCES}

B anihashemi Z., Dezeeuw D. J., 1973. The effect of soil temperature on survival of Fusarium oxysporum f. melonis (Leach and Currence) Snyd and Hansen. Plant and Soil 38 (2): 465-468 (Rev. of Plant Pathol. 53: 833).

B is by C. R., J a mes N., Timonin M., 1933. Fungi isolated from Manitoba soil by the plate method. Canad. Journ. of Res. 8: 3.

B o oth C., 1971. The genus Fusarium. Commonvealth Mycol. Inst. Kew. Surrey, pp. 221.

Buxton E. W., Kendrick J. B., 1963. A method of isolating Pythium spp. and Fusarium oxysporum from Soil. Ann. Appl. Biol. 51 (2): 215-221.

Czyżewska S., Z a r z y cka H., 1968. Aktualny stan wiadomości o fuzariozach lnu $w$ Polsce na podstawie dotychczasowych badań. - $\mathrm{Z}$ badań nad fuzario- 
zami lnu w Polsce i zaprawianiem nasion. Zesz. Inf. Inst. Przem. Włók. Łyk. 4, (1): 3-21.

Dom sch K. H., Gams W., Weber E., 1968. Der Einfluss verschiedener Vorfrüchte auf das Bodenpilzspektrum in Weizenfeldern. Z.-Pfl. Ernhr. Bodenk. 119. (2): 134-149.

Fedorinchik N. S., 1968. Priemy obogashchemya pochvennykh biotsenozov saprofitnym gribom Trichoderma lignorum Harz. antagonistom patogennykh mikroorganizmov. Trudy Vsekh. Inst. Zashch. Rast. 31: 344-350.

G a r ret S. D., 1946. Soil as a medium for transfer and multiplication of disease organisms. Soil Sci. 61 (1): 3-8.

$\mathrm{K}$ a u f m a n D. D., Wili a m s L. E., 1965. Influence of soil reaction and mineral fertilization on numbers and types of fungi antagonistic to four soil-borne plant pathogens. Phytopath. 55 (5): 570-574.

Kommendahl T., Christensen J. J., Frederiksen R. A., 1970. A half century of research in Minnesota on flax wilt caused by Fusarium oxysporum. Tech. Bull. Minn. Agric. Exp. Stn. 273: 35.

Korneeva E. M., 1971. O neobkhodimosti differentsiatsii fuzarioznykh zabolevanii lna - dolguntsa. Trudy Nauch. Issled. Lna 9: 341-360.

Krassilnikov N. A., 1946. Vliyanie rastitelnovo pokrova na mikrobnyi sostav pochvy. Mikrobiologiya 13 (5): 187-198.

Kryński J., Zarzycka H., 1972. Wylnienie gleby i możliwości zapobiegania mu. Kraj. Narada Agrotechn., Lublin 23 marca 1972: 39-46.

Le maire J. N., 1968. Compte-rendu d'activité des essais réalisés sur les maladies cryptogamiques du lin. Centre National des Recherches Agronomiques, Rennes, 9.

Maciejowska Z., 1967. Z badań nad mikroflorą gleby torfowej i jej wplywem na zdrowotność korzeni niektórych roślin kapustnych. Pr. nauk. Inst. Ochr. Rośl. 9 (2): 117-144.

Marchionat to J. B., 1951-52. Influencia de las practicas culturales en las enferme dades de la plantas. Alm. Minist. Agric. B. Aires. 86-87.

Messiaen C. M., M a s P., Beyries A., Vendran H., 1965. Recherches sur l'écologie des champignons parasites dans le sol. IV. Lyse mycelienne et formes de conservation dans le sol chez les "Fusarium". Annls Epiphyt. "16 (2): 107-128.

Meredith C. H., 1943. The antagonism of Actinomycetes to Fusarium oxyspo. rum cubense. Phytopath., 33 (5): 403.

$\mathrm{N}$ a sh S., Alexander J. V., 1965. Comparative survival of Fusarium solani f. cucurbitae and F. solani f. phaseoli in soil. Phytopath., 55 (9): 963-966.

Neafitava V. K., 1969. Uplyv se' skagaspadarchykh kultur na infeksyiny patentsyyal Fusarium oxysporum f. lini. Vestsi Akad. Navuk BSSR, ser. biyal Navuk 5: 30-34 (Rev. of Apl. Mycol. 49: 491).

Progress Report 1937-47, 1950. Fibre Central Experimental Farm. Ottawa, Canada. R a t a j K., 1954. Choroby přadnych rostlin - Fuzariozy. Praha, pp. 100.

Strzelczyk E., 1966. Effect of associated growth of bacteria from rhizosphere and nonrhizosphere soil on growth of fungi. Annls Inst. Pasteur. 11 (3). Colloquium of the Sect. Microbiol. dn. Sol. Soc. Fr. de Microbiol. 3-4 Feb. 1966.

Timonin M. J., 1940. The intereaction of higher plants and soil microorganisms. II. Study of the microbial population of the rhizosphere in relation to resistance of plants to soil-borne diseases. Canad. J. Res. Sect. C. 18 (9): 444-455. 
V an der S pek J., 1965. Botrytis cinerea als parasiet van Vlas. Versl. landbouwk. Onderz. Rijkslandb. Proefstn. 651: 146.

W nękowski S., 1966. Promieniowce z rodz. Streptomyces (Actinomycetes) wyizolowane z ziemi czarnej i próba określenia ich wpływu na rozwój niektórych fitopatologicznych grzybów glebowych. Pr. nauk. Inst. Ochr. Rośl. 8 (2): 71-152.

Z arzycka H., 1973. Badania nad zakażeniem gleby przez grzyby z rodzaju $F u-$ sarium patogeniczne dla lnu. Pr. Inst. Kraj. Włók. Natur. 20: 97-112.

Ziling N. K., 1932. Materialy k'poznaniu mikroflory počhv Zap. Sibirii. Predvaritelnyje itogi raboty 1931 g z Bolezni Zernovych Kultur. Omsk., pp. 40-61.

\section{Fluktuacje w zasiedlaniu gleby przez grzyby z rodzaju Fusarium} i rola przedplonu $\mathrm{w}$ walce $\mathrm{z}$ fuzariozą $\ln u$

\section{Streszczenie}

W Instytucie Krajowych Włókien Naturalnych w latach 1968-1975 badano wpływ płodozmianu i warunków atmosferycznych na zasiedlenie gleby przez grzyby z rodzaju Fusarium i na porażenie lnu przez fuzariozę.

Badania przeprowadzano w ciągu 8 lat w. różnych rejonach uprawy lnu w Polsce. Zmianowanie miało wyraźny wpływ na proces biologicznego oczyszczenia gleby. Stopień zasiedlenia gleby przez grzyby z rodzaju Fusarium wzrastał po uprawie lnu, pszenicy, jęczmienia i buraków cukrowych, a spadał lub nie ulegał zmianie po rzepaku, konopiach, ziemniakach i roślinach motylkowych. Zmianowanie miało wpływ na skład gatunkowy Fusarium spp. w glebie. Najsilniejsze porażenie roślin obserwowano po lnie, burakach cukrowych i pszenicy, a najsłabsze po rzepaku. Na ogół 6-letnia przerwa między jedną uprawą lnu a drugą była wystarczająca, aby zmniejszyć populację grzybów z rodzaju Fusarium w glebie do poziomu nie stanowiącego zagrożenia dla plantacji lnu. Lecz na glebach wylniałych proces biologicznego oczyszczania przebiegał wolno i nawet 7letnia przerwa między uprawami lnu okazała się zbyt. krótka. 